\title{
Is informality a barrier to financial development?
}

\author{
Ceyhun Elgin • Burak R. Uras
}

Received: 11 May 2012 / Accepted: 17 October 2012 / Published online: 4 November 2012

(C) The Author(s) 2012. This article is published with open access at SpringerLink.com

\begin{abstract}
This study investigates the relationship between financial development and the size of the informal economy. We build a model in which an exogenous variation in the size of the informal sector creates two effects on financial development. Specifically, informal sector harms financial development through increasing financial repression due to tax evasion. However, on the other hand, increasing informal sector size facilitates financial development through easing the capacity constraint on the financial sector. Using a cross-country panel data set of 152 countries over the period 1999-2007 we also provide empirical support for the mechanism of our theory.
\end{abstract}

Keywords Financial development · Informal sector

JEL Classification $\quad \mathrm{E} 02 \cdot \mathrm{G} 28 \cdot \mathrm{H} 59$

\section{Elgin $(\varangle)$}

Department of Economics, Bogazici University, Natuk Birkan Binasi Kat: 2 Bebek,

34342 Istanbul, Turkey

e-mail: ceyhun.elgin@boun.edu.tr

B. R. Uras

Department of Economics, Tilburg University, Room K322B, 5000 LE,

Tilburg, The Netherlands

e-mail: r.b.uras@uvt.nl

B. R. Uras

European Banking Center, Room K316, 5037 AB, Tilburg, The Netherlands

B. R. Uras

CentER, Room K214, 5037 AB, Tilburg, The Netherlands 


\section{Introduction}

Financial development is clearly an important indicator of the long-run macroeconomic development. There is a vast empirical literature focusing on the relationship between the level of financial development and long-run economic performance. ${ }^{1}$ Similarly, tax evasion and the extent of the informal activity are among key issues affecting the economic and institutional development of a society (see Johnson et al. 1997, 1998; Torgler and Schneider 2007 and much more recently Elgin 2010 among many others.). Even though informality ${ }^{2}$ is prevalent and poses serious economic, social and political challenges across the world many issues about the nature and consequences of informality remain largely under-explored or unresolved. For example, the evidence presented in the existing literature, has failed to generate a consensus around the determinants and consequences of the informal sector among researchers. There are also many other open questions including even such basic ones such as whether informal sector size would be larger in low income or high income nations (see Dreher and Schneider 2010); whether taxes are positively correlated with informal sector size or not (see Schneider and Enste 2000; Friedman et al. 2000; Elgin 2010 among many others.) or whether shadow economy and corruption are substitutes or complements (Dreher and Schneider 2010).

In this paper, combining these two strands of the literature, we explore the effects of the size of the informal sector on financial sector development. We define the level of financial development as the fraction of external finance over total income in the formal sector and show in a theoretical model that there exists an inverted-U relationship between the level of financial development and the size of informal sector. The effects of informality on financial sector repression in the presence of financial sector capacity constraints is central to our theory. Specifically, for a given state of institutional development we show that high levels of informal activity increases the level of financial repression in the formal financial sector and therefore suppressing the informal sector size benefits the level of financial development in the economy. However, if the initial level of informal sector size is small enough, the losses due to financial repression are negligible in the formal financial sector. In this latter case, if the capacity constraints of the formal financial institutions are binding, lowering the size of the informal sector would retard the level of financial development. We also support our theoretical prediction in a cross-country panel data analysis and present robust empirical evidence for the existence of an inverted-U relationship between financial development and the size of the informal sector.

Theoretical studies on financial development are various. Some of the significant contributions in this area are Greenwood and Jovanovic (1990), Bencivenga

\footnotetext{
1 See for example Levine (1993, 1997), Beck et al. (2000), Arestis and Demetriades (1997), Calderon and Liu (2003), Christopoulos and Tsionas (2004), and Beck et al. (2008).

2 Informal economy or informal sector, sometimes also called as shadow, hidden or underground economy is defined by Hart (2008) as a set of economic activities that take place outside the framework of bureaucratic public and private sector establishments. Similarly, Ihrig and Moe (2004) defines it as a sector which produces legal goods, but does not comply with government regulations.
} 
and Smith (1991), Marcet and Marimon (1992), Banerjee and Newman (1993), Acemoglu and Zilibotti (1997), Aghion and Bolton (1997), Azariadis and Kaas (2007), Antunes et al. (2008), and Aghion et al. (2010). Our work abstracts away from studying the positive effects of financial development on aggregate economy and instead concentrates on the contribution of the size of informal sector in explaining society's financial development. In this respect our work is closely related with Greenwood and Jovanovic (1990) and Acemoglu and Zilibotti (1997) where the level of financial sector development is to be determined endogenously in the model.

Notwithstanding there are other studies that are concerned with the interrelation between finance and informal sector size. We can list Straub (2005), Amaral and Quintin (2006), Antunes and Cavalcanti (2007), Beck et al. (2009) much more recently Massenot and Straub (2011), as important contributions to this literature. The common motivation point of these studies is that the magnitude of credit market imperfections in the formal sector constrains the outside finance for entrepreneurial firms and magnifies the size of the informal activity. The study that gets closest to the central motivation of our paper is Massenot and Straub (2011). In Massenot and Straub (2011) setting, an exogenously given level of credit market frictions (entry costs to be more precise) affects the size of the formal activity and in turn the supply and also demand for credit simultaneously as in Castro et al. (2004). Different from their work, in our model the exogenous variation in the size of the informal activity affects the extent of credit market frictions. Therefore, to the best of our knowledge our paper is the first to analyze the reverse causality between the size of informal sector on the availability of external finance in the formal sector.

The theoretical framework we study rests on stylized empirical differences between formal and informal sector production. Specifically, in our model formal sector entrepreneurs pay taxes and borrow and lend in the financial market at an endogenous cost of external finance to insure against idiosyncratic production risk. Informal sector entrepreneurs do not pay taxes and do not have access to external financing. We assume that the government has to collect a given amount of tax revenue from the public. Due to the existence of tax evasion in the economy, the government has to rely on indirect taxation through the financial intermediary. We model the indirect financial sector taxes as financial repression á la Roubini and Sala-i Martin (1992) and Roubini and Sala-i Martin (1995). Roubini and Sala-i Martin (1992) and Roubini and Sala-i Martin (1995), Aruoba (2010), and Cavalcanti and Villamil (2012) show that in the presence of large tax evasion the optimum level of inflation and optimal financial repression is greater than zero. We structure the model in such a way that the endogenous financial repression in the economy is a decreasing function of the size of the informal sector. Furthermore, we assume that the banking sector of the economy functions under capacity constraints. Capacity constraints at the financial sector is a well established characteristic assumption of the Costly-State-Verification (CSV) models of banking pioneered by Townsend (1979), Williamson (1987), and Diamond (1991). In CSV models monitoring costs of the banking sector are represented by a convex-cost function. Following the CSV literature we also adapt a standard convexcost function for the financial intermediary sector. Our highlighted analytical results are as the following: When the size of the informal sector decreases, the marginal cost of external finance in the formal sector declines as a result of the decline in the 
level of financial repression whereas at the same time since the demand for external funds in the formal sector rises marginal cost increases due to the presence of convex monitoring costs. If the gains due the decline in financial repression outweighs the losses due capacity constrains, the contraction in the informal sector size stimulates the size of the formal external financing. Otherwise, a contraction in the size of the informal activity crowds outside financing in the formal economy.

Empirically, using a cross-country panel data set of 152 countries over the period 1999-2007 we provide a robust support in favor of the presence of an inverted-U relation between the size of the informal sector and financial development. Moreover, using panel system estimations we also present evidence in supporting for the mechanism of our model. Specifically, we show that informal sector is positively related to the proxies of financial repression and financial sector efficiency.

The rest of the paper is organized as follows: In the second section of the paper we build the theoretical framework which we want to utilize to account for the proposed relationship between financial development and informality. Next, in the third section we conduct an empirical analysis and establish a robust inverted-U relationship between financial development and the size of the informal sector, even after controlling for various variables that might be associated with the level of financial development. Finally, we provide concluding remarks in the last section.

\section{Model}

The economy consists of a continuum of entrepreneurs with a unit measure. Each agent in the economy is endowed with a stochastic production technology. The production returns are linear in factor inputs. Specifically, each entrepreneur produces $A x$ units of the consumption good with probability $p$ for each $x$ units of working capital invested. With probability $(1-p)$ the technology returns 0 units of the consumption good. Idiosyncratic production returns are independent and identically distributed across entrepreneurs. Therefore an aggregate $p$ fraction of the entrepreneurial population experiences the positive return realization whereas the $1-p$ fraction of the entrepreneurs experience the zero return realization. The idiosyncratic realization of the output state is private information to the entrepreneur and can only be verified (and enforced) by banks at a unit monitoring cost of external finance, $c_{F}$. Bank's monitoring cost will be delineated below.

Each entrepreneur is also endowed with $w$ units of the capital good. There are two means of investment for entrepreneurial capital endowment: (1) An entrepreneur can invest the capital good in his own stochastic production technology, or (2) he can deposit the capital endowment at the bank. If he chooses the latter option, he will obtain a deterministic $R x$ units of the consumption good for each $x$ units of capital deposited at the bank where the deposit interest rate $R$ is to be determined endogenously.

Upon collection of returns from the stochastic production technology and the bank deposits entrepreneurs consume. Denote the consumption of an agent with $C$. There are two types of entrepreneurs: Risk-averse type entrepreneurs and risk-neutral type entrepreneurs. A $\zeta$ fraction of all entrepreneurs are risk-averse. Risk averse entrepreneurs have a concave utility function with properties $U^{\prime}(C)>0, U^{\prime \prime}(C)<0$ with $U(0)=0$. Therefore, risk-averse types desire to smooth consumption across different 
realizations of stochastic production returns by investing a fraction of their entrepreneurial wealth at the bank. The larger the concavity of the utility function, the larger is the fraction of the capital endowment that risk-averse entrepreneurs are willing to deposit at the bank. In equilibrium the risk-averse types will be the net lenders of investable funds in the economy (financiers). Risk-neutral entrepreneurs have a linear utility function as $U(C)=C$. In equilibrium the risk-neutral type entrepreneurs will be the net borrowers of investable funds (borrowers).

There are two sectors in the economy: (1) $\alpha$ fraction of the entrepreneurs operate in the formal sector. Formal sector entrepreneurs have access to financial services through which they can borrow and lend investable funds. In addition to this, also each formal sector entrepreneur pays a lump-sum tax of $t$ for his production technology use. (2) $(1-\alpha)$ fraction of the entrepreneurs operate in the informal sector. Informal entrepreneurs have no access to the financial sector, and they do not pay any taxes. Without loss of generality we assume that an $\alpha$ fraction of the entrepreneurs are allocated to the formal sector exogenously. ${ }^{3}$

Banks There is a bank (representative financial sector) in the economy which receives capital (deposits) from formal sector agents and invests the deposited capital endowments across production technologies of a distribution of formal entrepreneurs. The rationale for the existence of a bank in the economy is due to the risk diversification capacity of the banking system. Banks diversify the idiosyncratic production risk by investing each unit of deposited capital across a continuum of entrepreneurs. Hence, banks can promise a deterministic deposit interest rate $R$ for each unit of endowment deposited at the bank. The risk diversification is associated with a marginal cost of financial transactions $c_{F}$. There are two components of $c_{F}$ : (1) Production monitoring cost and (2) Financial repression.

Monitoring Bank has to incur a cost of monitoring for each unit of capital invested at a particular entrepreneur's production technology. The underlying motive for bank's monitoring is as follows: Production realizations are private information, therefore repayments on un-monitored external finance cannot be extracted from the entrepreneur. Specifically, if not monitored an entrepreneur with positive return realization would claim that he had the zero-return state realization and strategically default to enjoy private gains on his externally financed fraction of entrepreneurial output. Therefore, in order to avoid strategic default and enforce repayment, the bank monitors production realizations. We assume that the financial sector has a capacity to monitor projects: The bank has a convex cost of monitoring projects for each fund deposited at the bank.

Financial repression We assume that the government has to collect an exogenously given amount of tax revenue from the formal sector entrepreneurs to finance government purchases. The government collects $\alpha t$ units of tax revenue directly from the formal sector enterprises. Roubini and Sala-i Martin (1992, 1995) empirically show that economies with large tax evasion use financial repression (a financial transactions

\footnotetext{
3 The framework can be generalized to a model of endogenous choice of informality. For example a set-up where the distribution of entrepreneurs are heterogeneous in risk aversion. In such a model, entrepreneurs with higher risk aversion would self-select themselves into formal sector to utilize financial services.
} 
tax) as an indirect method of taxation which in turn increases the marginal cost of financial intermediation.

Putting these two costs together, the aggregate cost of financial intermediation in the economy is given by:

$$
C_{F}=C_{r}+\frac{B}{\gamma-1} W^{\gamma}
$$

Financial intermediation costs $C_{F}$ as delineated before has two components. The first component, $C_{r}$, is the cost of financial repression due to tax evasion. The second component is the convex monitoring costs: $W$ is the total quantity of capital deposited at the financial intermediary which is to be determined in equilibrium. $B>0$ and $\gamma>1$ are structural parameters determining the efficiency of the financial system at monitoring entrepreneurial production returns. The larger $B$ and $\gamma$ the higher is the cost of financial intermediation.

As in Roubini and Sala-i Martin $(1992,1995)$ we assume that the aggregate financial repression in the economy is proportional to the aggregate tax evasion, or formally $C_{r}=\kappa W$ where $\kappa$ is the rate of financial repression with $\partial \kappa / \partial \alpha<0$. Denote the per-capita quantity of capital endowment deposited at the bank as $w^{E}$. We can state the unit cost of financial intermediation per capital invested as:

$$
c_{F}=\kappa+\frac{B}{\gamma-1}\left(\alpha w^{E}\right)^{\gamma-1}
$$

Finally, we assume that a zero profit condition holds for the bank and lending contracts with entrepreneurs are governed by limited liability. Limited liability implies that following the realization of production state entrepreneurs repay to the bank only when a positive return realization occurs. Denote $r$ as the ex-ante repayment rate charged to an entrepreneur (at a positive return realization state) for each unit of capital financed externally. Bank's zero profit condition implies that $r$ (borrowing rate of interest) and $R$ (deposit rate of interest) should satisfy

$$
r-c_{F}=R
$$

where the unit cost of monitoring $c_{F}$ endogenously determines the interest rate spread, or in other words the efficiency of the financial sector, in the economy.

In this environment risk-averse entrepreneurs supply the bank deposits. Their savings, as emphasized previously, is purely driven by risk-diversification motives. Riskneutral entrepreneurs invest the entirety of their personal capital holdings in their own investment projects and demand external capital (borrow) from the bank. The interest rate spread $r>R$ ensures that the risk-neutral entrepreneurs are net borrowers in the economy. This qualitative feature of the model does not contradict with empirically observed firm-capital structure patterns: A large fraction of firm owners, including highly leveraged small and medium size enterprises, do not invest a large fraction of their personal assets in their own production units so that they could diversify idiosyncratic production risk. One exception to this could be the heavily financially constrained micro-enterprises that tend to invest almost $100 \%$ of their personal assets 
in their own companies. This observation however does not conflict with our model either since one could easily argue that such enterprises are more inclined towards informal sector production. In our set-up informal sector entrepreneurs do not diversify production risk and invest $100 \%$ of their personal asset holdings in their own investment projects.

\subsection{Entrepreneur's problem}

Entrepreneur's problem in the informal sector is trivial. Each informal entrepreneur invests the entirety of his endowment in his own production technology and earns $A w$ with probability $p$. Hence the expected utility of an informal agent (I) equals to:

$$
E_{I}\left[U\left(C_{I}\right)\right]=p U(A w) .
$$

A formal sector entrepreneur who is risk-averse on the other hand optimally allocates his capital endowment $w$ between his own production technology ( $w^{I}$ of $w$ ) and bank deposits $\left(w^{E}\right.$ of $\left.w\right)$. Given the formal sector taxes $t$ and the unit cost of financial intermediation $c_{F}$, a formal sector $(\mathrm{F})$ entrepreneur's optimization problem is given as the following:

$$
\begin{aligned}
\max _{w^{I}, w^{E}} E_{F, A}\left[U\left(C_{F}\right)\right]= & p U\left(A w^{I}-t+R w^{E}\right)+(1-p) U\left(-t+R w^{E}\right) \\
\text { s.t. } & w^{I}+w^{E}=w
\end{aligned}
$$

Denote the external capital demand of risk-neutral entrepreneurs from the bank by $w^{X}$. Risk-neutral entrepreneurs' profit maximization problem in formal sector is given by:

$$
\max _{w^{X}} E_{F, A}\left[U\left(C_{F}\right)\right]=p A w+(p A-r) w^{X}-t
$$

In equilibrium the supply of aggregate deposits will be equal to the aggregate demand for external capital in the following way

$$
\zeta w^{E}=(1-\zeta) w^{X}
$$

\subsection{Equilibrium}

Definition 2.1 The equilibrium of the economy is given by deposit and borrowing interest rates $\left(r\right.$ and $R$ ) and the endogenous unit cost of monitoring $\left(c_{F}\right)$ at which formal sector risk-averse entrepreneurs optimize endowment allocation choice between risky-investment and bank deposits $\left(w^{I}\left(c^{*}\right)\right.$ and $\left.w^{E}\left(c^{*}\right)\right)$, risk-neutral entrepreneurs optimize external finance, the capital market clears and the zero profit condition for the bank holds.

Lemma 2.2 The equilibrium interest rates satisfy the following relation:

$$
R=r-c_{F}=p A-c_{F} .
$$


Proof The first equality follows from the zero profit condition of the bank. The second equality follows from the competitive capital market condition. In equilibrium $\zeta w^{E}=$ $(1-\zeta) w^{X}$ holds. Therefore, each unit of capital deposited at the bank is invested at an entrepreneurial production technology of a risk-neutral entrepreneur. Suppose $r<p A$, since expected profits from borrowing one more unit of capital is positive for a risk-neutral entrepreneur, risk-neutral entrepreneur's capital demand and hence the interest rate charged on externally financed capital rises until $r=p A$. The linearity of the production function, or in other words the absence of decreasing returns to scale guarantees this result. An analog argument can be exploited for the case of $r>p A$.

Lemma 2.2 implies that risk-neutral entrepreneurs do not capture a positive surplus from the externally financed fraction of their production activity. This implication is related to the linear production technology specification.

Optimizing (3) subject to (4) and the equilibrium condition provided at lemma 2.2, we can derive the marginal rate of substitution for a risk-averse entrepreneur across the two states of production. Namely, we can derive MRS as a function of entrepreneurial deposits $w^{E}$ :

$$
\frac{U^{\prime}\left(A\left(w-w^{E}\right)-t+p A w^{E}-c w^{E}\right)}{U^{\prime}\left(-t+p A w^{E}-c w^{E}\right)}=\frac{(1-p)(p A-c)}{p(A-p A+c)}
$$

Since the utility is concave we can derive the optimum $w^{E}$ (or $w^{X}$ ) as a function of $c_{F}$. Comparative statics show that $w^{E}(c)=w^{X}(c)$ is monotonically decreasing. Assigning a functional form for $U(C)$, one can explicitly solve for $w^{E}\left(c_{F}\right)$. Equilibrium unit cost of financial intermediation $c_{F}^{*}$ can be found by plugging $w^{E}\left(c_{F}\right)$ in (1) and solving for $c_{F}^{*}$.

\subsection{Comparative statics}

In this section, we study the effects of a decrease in the size of the informal sector, specifically a rise in $\alpha$, on the level of financial development in the society. We define society's financial development with the fraction of total credit divided by the total capital investment in the formal sector: $\frac{\alpha \zeta w^{E}}{\alpha w}=\frac{\zeta w^{E}}{w}$. Since $\zeta$ is a constant, the higher the external finance, the higher is the level of financial development.

Therefore, in the model the size of informality affects the financial development to the extent it affects the marginal cost of financial intermediation in the formal sector. There are two channels through which the size of the formal sector could stimulate $c_{F}$ : (1) financial repression, (2) increasing the aggregate demand for financial intermediation where through the former channel the size of the informal sector affects the financial sector development in a negative way (more informality is bad for financial development because of financial repression), whereas through the latter channel it affects financial development in a positive way (more informality is good for financial development because of financial sector's capacity constraint).

Since $c_{F}^{*}$ is determined by (1) in equilibrium, we can study the effects of informal sector size on financial development by totally differentiating both sides of (1) with respect to $\alpha$ (the size of the formal sector). Totally differentiating (1) we can show that: 


$$
\begin{array}{r}
\frac{\partial c^{*}}{\partial \alpha}=\frac{\partial \kappa}{\partial \alpha}+B\left(\alpha w^{E}\left(c_{F}^{*}\right)\right)^{\gamma-2}\left(w^{E}\left(c_{F}^{*}\right)+\alpha \frac{\partial w^{E}\left(c_{F}^{*}\right)}{\partial c_{F}^{*}} \frac{\partial c_{F}^{*}}{\alpha}\right) \\
\frac{\partial c^{*}}{\partial \alpha} \underbrace{\left(1-B \alpha\left(\alpha w^{E}\right)^{\gamma-2}\left(c_{F}^{*}\right) \frac{\partial w^{E}\left(c_{F}^{*}\right)}{\partial c_{F}^{*}}\right)}_{\Delta}=\underbrace{\frac{\partial \kappa}{\partial \alpha}+B\left(\alpha w^{E}\left(c_{F}^{*}\right)\right)^{\gamma-2} w^{E}\left(c_{F}^{*}\right)}_{\Gamma(\alpha)}
\end{array}
$$

Since $\Delta$ is positive we can derive the following result about $\Gamma(\alpha)$.

Proposition 2.3 For a given level of $c^{*}$, there exists an $\alpha^{*}$ such that $\Gamma(\alpha)$ is negative (the marginal financial intermediation cost $c^{*}$ is decreasing) in $\alpha$ for all $\alpha \in\left[0, \alpha^{*}\right]$, and positive (the marginal financial intermediation cost $c^{*}$ is increasing) in $\alpha$ for all $\alpha \in\left[\alpha^{*}, 1\right]$.

Proof We assumed that financial repression is a decreasing function of the formal sector size: $\partial \kappa / \partial \alpha$. Therefore, $\Gamma(\alpha)$ is negative when $\left|\frac{\partial \kappa}{\partial \alpha}\right|>B\left(\alpha w^{E}\left(c_{F}^{*}\right)\right)^{\gamma-2} w^{E}\left(c_{F}^{*}\right)$. This condition holds when $\alpha$ is small enough:

$$
\alpha<\left(\left|\frac{\partial \kappa}{\partial \alpha}\right|\left[\frac{1}{B\left(w^{E}\left(c^{*}\right)\right)^{\gamma-1}}\right]\right)^{\frac{1}{\gamma-2}} \equiv \alpha^{*} .
$$

The proposition shows that the effects of $\alpha$ (or the size of the informal sector) on financial development is non-monotonic. For a given level of institutional development (financial repression and bank's cost of monitoring), if the initial size of the informal sector is large enough (or in other words if the formal sector size is small), a contraction in the size of the informal sector and the implied reduction in tax evasion improves society's financial development. The intuition behind our result is straightforward: Given the capacity of the financial sector (determined by quadratic cost function), if the financial repression due to tax evasion is high enough, decreasing the size informal sector would improve society's financial market activity. If on the contrary the initial size of the informal sector is too small, a contraction in the size of the informal sector retards the level of financial development. In this case the size of the formal sector is too large that a marginal reduction in the size of informality makes the capacity constraint of the banking sector become relevant for the magnitude of financial intermediation costs. In the next section we will provide a cross-country empirical analysis to test these qualitative predictions of our model.

\section{Empirical analysis}

In this section we run panel regressions to gain a deeper understanding of the relationship between financial development and the size of the informal sector. In the first subsection below, we first discuss how we select our variables and our data sources. In the second subsection we establish a robust inverse-U relationship between informal sector size and financial development. Finally, the last subsection is devoted to empirical testing of the model of the previous section. 


\subsection{Data}

\subsubsection{Variable selection}

As measures of financial development we use three variables that are widely used in the literature as proxies for financial development. These are domestic credit provided by banking sector (\% of GDP), shortly denoted by CRD, domestic credit to private sector (\% of GDP), shortly denoted by CRBAN and finally money and quasi money. (M2 as \% of GDP).

Moreover, in order to separate the effect of the variation in the size of the informal sector on the variation in the level of financial development, we use various control variables most of which are widely employed in the empirical literature on financial development. Our control variables are GDP per-capita (Chinn and Ito 2006; Huang 2010 among many others) current account balance (see Chinn and Ito 2006, 2007) (net export as \% of GDP is used as a proxy), tax burden defined as the tax revenue as \% of GDP (Roubini and Sala-i Martin 1995; Huang 2010), inflation based on the consumer price index (see Boyd et al. 2001), capital-output ratio (see Beck et al. 2000; Schich and Pelgrin 2001) and three institutional quality (Chinn and Ito 2006; Huang 2010) variables, namely law and order, bureaucratic quality and corruption control indices. Ceteris paribus, we expect that higher values for institutional quality variables should be associated with a higher level of financial development as they improve the political and economic environment for the financial sector. Similarly, we expect a positive correlation for GDP per-capita as well as capital-output ratio. On the other hand, considering that current account and capital account sum up to zero, we expect a negative correlation between current account balance and financial development. As for inflation and tax burden our a-priori expectations are ambiguous. Inflation is certainly harmful for financial development at relatively high levels, however there is also a substantial literature arguing that this relationship is a nonlinear one, in that there is a threshold level of inflation below which inflation has a positive effect on financial depth. ${ }^{4}$ As for taxes, an increasing tax burden might harm financial development through the distortions it creates. However, on the other hand, taxes are also necessary for a well-functioning government to enforce contractual agreements and property rights. In that sense, taxes can also be seen as the degree of government functionality which would foster financial development.

\subsubsection{Data sources}

We use panel estimates of Schneider et al. (2010) running from 1999 to 2007 which uses a dynamic version of MIMIC (multiple-indicator multiple-cause) approach to estimate the size of the informal economy. ${ }^{5}$ Our informal sector data covers 152 countries over a time span of 9 years.

\footnotetext{
4 For example see Khan et al. (2006).

5 See Schneider and Enste (2000), Schneider (2002, 2005) and Schneider, Buehn and Montenegro (2010) for details and an explanation of superiority of this methodology to others and comparisons of various methods previously used to estimate the size of the informal sector.
} 
Table 1 Complete dataset summary statistics

\begin{tabular}{lrrrr}
\hline & Mean & Std. Deviation & Minimum & Maximum \\
\hline Informal sector size (in \%) & 34.60 & 13.54 & 8.40 & 72.5 \\
Credit to private sector (\% of GDP) & 42.81 & 43.40 & 0.00 & 319.48 \\
Credit provided by the banking sector (\% of GDP) & 54.77 & 56.84 & -67.50 & 439.97 \\
M (\% of GDP)2 & 47.08 & 39.03 & 4.20 & 279.80 \\
Law and order index & 3.89 & 1.35 & 0.50 & 6.00 \\
Bureaucratic quality index & 2.23 & 1.11 & 0.00 & 4.00 \\
Corruption control index & 2.78 & 1.22 & 0.00 & 6.00 \\
Current account balance (in \%) & -3.06 & 59.96 & -253.00 & 364.47 \\
Capital-output ratio & 2.33 & 1.97 & 0.74 & 10.91 \\
Tax burden (in \% GDP) & 17.16 & 7.07 & 0.82 & 57.49 \\
Inflation (in \%) & 2.06 & 11.48 & -9.82 & 103.431 \\
(real) GDP per-capital (thousand USD) & 7.13 & 10.40 & 0.08 & 56.62 \\
\hline
\end{tabular}

Measures of financial development and inflation are all extracted from the World Development Indicators (WDI) of the World Bank. Similarly, we also obtain the tax burden from WDI. As a measure for corruption control, we use the corruption control index of the International Country Risk Guide (ICRG) provided by the Political Risk Services (PRS). Similarly, the indices of bureaucratic quality and law and order are obtained from ICRG, as well. These three variables aim to control for institutional quality. PRS constructs these estimates using expert opinions as a weighted average of various subindices. ${ }^{6}$ The greater values of these indices imply higher institutional quality.

The data on GDP per-capita and openness (defined as the ratio of the sum of exports and imports to aggregate GDP) come from the Penn World Tables (PWT) 7.0. Finally, to create the series for capital-output ratio we simply employ the the perpetual inventory method using the following system of equations:

$$
\begin{array}{r}
K_{t+1}=K_{t}(1-\delta)+I_{t} \\
\frac{K_{1998}}{Y_{1998}}=\frac{\sum_{i=1998}^{2007} \frac{I_{i}}{Y_{i}}}{\delta+g_{Y}}
\end{array}
$$

Equation (1) is the standard law of motion for capital, where $K_{t}$ stands for the aggregate capital stock in year $t, \delta$ for the depreciation rate of physical capital, and $I_{t}$ for the amount of investment in year $t .{ }^{7}$ Equation (2) is based on the assumption that the economy is at the steady state in the initial period of analysis which we take as 1998 here. Once the capital stock in 1998 is calculated using equation Eq. (2), Eq. (1) allows us to create a capital stock series for the years between 1998 and 2007. Finally, we divide the capital stock by real GDP to obtain the capital-output ratio. Descriptive statics of all the variables are provided in Table 1.

\footnotetext{
6 See http://www.prsgroup.com/ICRG_Methodology.aspx for more details.

7 We set $\delta=0.05$ and obtain the data on investment from PWT 7.0.
} 
3.2 Empirical results: financial development versus informal sector

In this subsection, we intend to find a robust relationship between financial development and informal sector size. To this end, the static panel equations we estimate are of the following form:

$$
F D_{i, t}=\beta_{0}+\beta_{1} i s_{i, t}+\beta_{1} i s_{i, t}^{2}+\sum_{k=3}^{n} \beta_{k} X_{k_{i, t}}+\theta_{i}+\gamma_{t}+\epsilon_{i, t}
$$

where $F D_{i, t}$ is the level of financial development of country $i$, in year $t$, and $i s_{i, t}$ is the informal sector size. Moreover, $X_{k_{i, t}}$ are the other explanatory variables in addition to informal sector and $\theta_{i}, \gamma_{t}$ are the country and period fixed effects, respectively. Finally, $\epsilon_{i, t}$ denotes the error term.

In most regressions we use the fixed-effect estimator in the static panel data setting. However, one might very much suspect the potential endogeneity of informal sector size as well as other control variables used in the above regression equation. Unfortunately, in the empirical literature on informality there is no consensus on what the right instrument of informal sector size is. One shortcut we can conduct at this point is to estimate the equation above with instrument variable (IV) estimation using the lagged values of independent variables as instruments. Therefore, in every table below, in addition to the fixed effect estimates, we also report IV estimates using separate columns.

Moreover, to capture persistence and also potentially mean-reverting dynamics in financial development we also report results of the dynamic panel data estimation using the GMM estimator developed by Arellano and Bond (1991) where one-period lagged values of the regressors are used as instruments. ${ }^{8}$ In this case we estimate the following equation:

$$
F D_{i, t}=\beta_{0}+\beta_{1} F D_{i, t-1}+\beta_{2} i s_{i, t}+\beta_{3} i s_{i, t}^{2}+\sum_{k=4}^{n} \beta_{k} X_{k_{i, t}}+\theta_{i}+\gamma_{t}+\epsilon_{i, t}
$$

Both in the IV and dynamic panel data estimations, $p$ values corresponding to two tests are also provided in all of the tables. One of these tests is the Hansen $J$ test for over-identifying restrictions and the other one is the AR (2) test for autocorrelation. The tests provide support for the exogeneity of the instruments and absence of autocorrelation in the specified order, respectively.

As mentioned above, we use three different variables as measures of financial development. We report regression results associated with each variable separately. To this end, Table 2 presents regressions with Credit to Private Sector to GDP ratio as the relevant measure of financial development.

\footnotetext{
${ }^{8}$ Further estimations has been conducted to address potential existence of a two-directional causality between informal sector size and measures of financial development. We also run regressions using the IV estimator of Anderson and Hsiao (1982). These are available upon request from the corresponding author.
} 


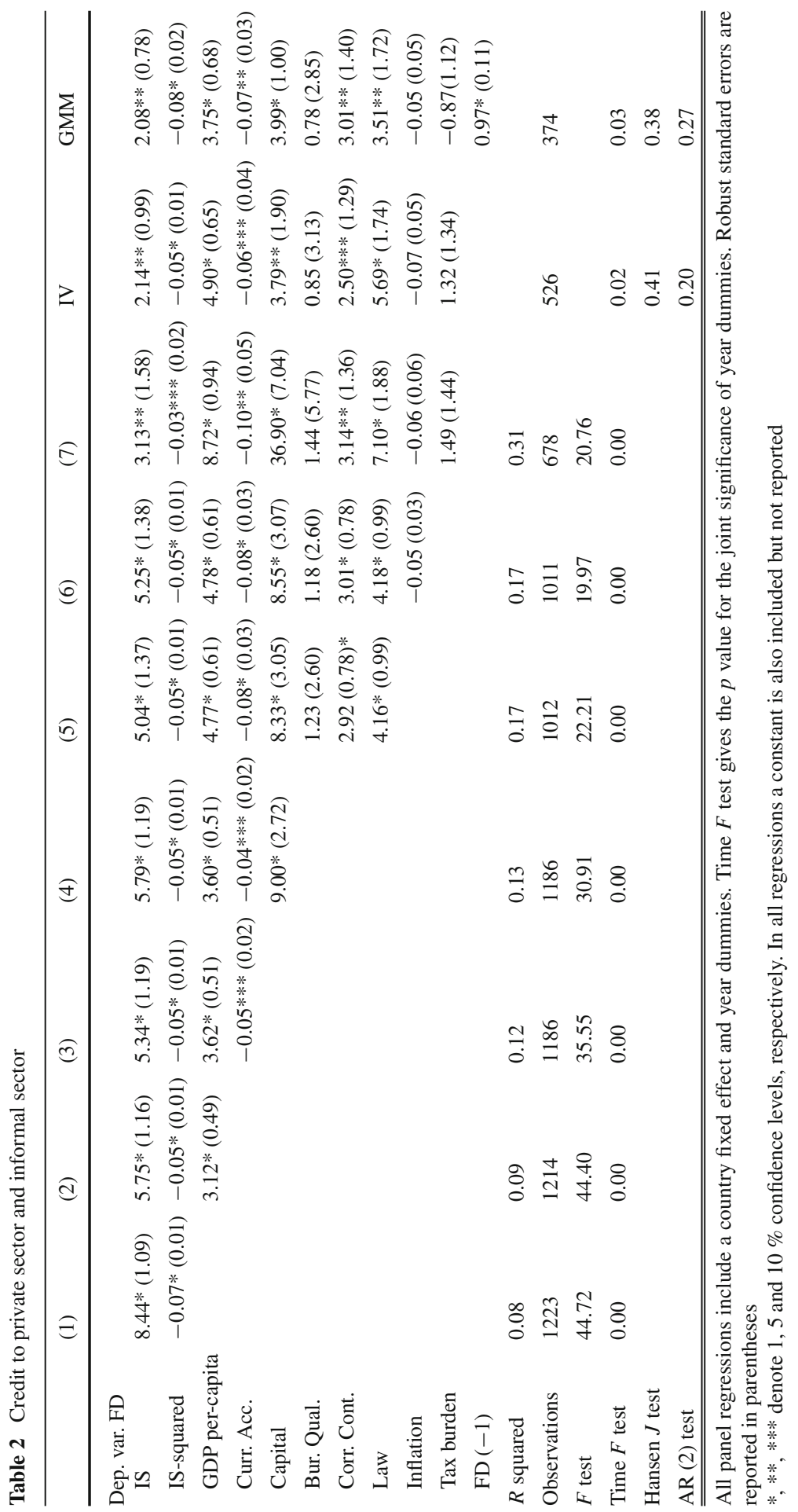


In Table 2 we report 9 regressions. In the first seven regressions, we present results of the fixed-effect linear panel estimation with an AR(1) disturbance ${ }^{9}$ with different independent variables in each. Moreover, in addition to these seven regressions, we also report the coefficients of the regression with the IV estimation and finally the dynamic panel data estimation using the GMM estimator.

As both the coefficient for informal sector size and squared informal sector size are significantly positive and negative, respectively, the inverted-U relationship between credit to private sector (\% of GDP) as a measure of financial development and informal sector is robust to the inclusion of different control variables to the regression equation or use of different econometric specifications.

Other than informal sector size, other factors that seem to be robustly correlated with credits to private sector are GDP per-capita, current account balance, capitaloutput ratio, corruption control and law and order indices. Noticeably, coefficients of all these variables have expected signs.

Tables 3 and 4 on the other hand, report regression results using domestic credit provided by the banking sector \% of GDP and M2 \% of GDP as measures of financial development. Explanatory variables used in these regressions are the same as the previous one. In summary, again here empirical results support the inverted-U relationship between informal sector size and financial development. Again in both tables, we observe that both the coefficient for informal sector size and squared informal sector size are significantly positive and negative, respectively.

In addition to informal sector size, we see that GDP per-capita and capital-output ratio is robustly correlated with credits provided by banking sector. Other than these current account balance, corruption control and law and order indices produce significant coefficients in some regressions, but not in all. As for M2, the only robustly correlated variable other than informal sector size is the corruption control index. However, the somewhat surprising thing is that corruption control index is negatively correlated with M2. Moreover, in some regressions GDP per-capita, capital-output ratio, tax burden, law and order and bureaucratic quality indices are also correlated with M2.

Considering that the time-series dimension of our dataset is limited and the financial development-informal sector relationship might have a similar path across countries one might want to check results of ordinary-least squares (OLS) regressions. The advantage of an OLS regression here is that it gives an idea of the longer term relationship between financial development and the informal sector size. Therefore, to check for robustness, in addition to the fixed-effect regressions we also run OLS regressions using pooled data. ${ }^{10}$ Since there are no country fixed effects in the OLS specification, we also introduce dummy variables to represent several country groups. These are dummies for Subsaharan African, highly developed countries (DC), Latin American and Caribbean and MENA countries. This is to capture the common institutional characteristics share by countries in each group.

\footnotetext{
9 Hausman test points us in favor of a fixed-effect regression and Wooldridge test rejects absence of autocorrelation.

10 Actually, the Breusch and Pagan Lagrange multiplier test rejects the null hypothesis that the OLS is the appropriate estimation method.
} 


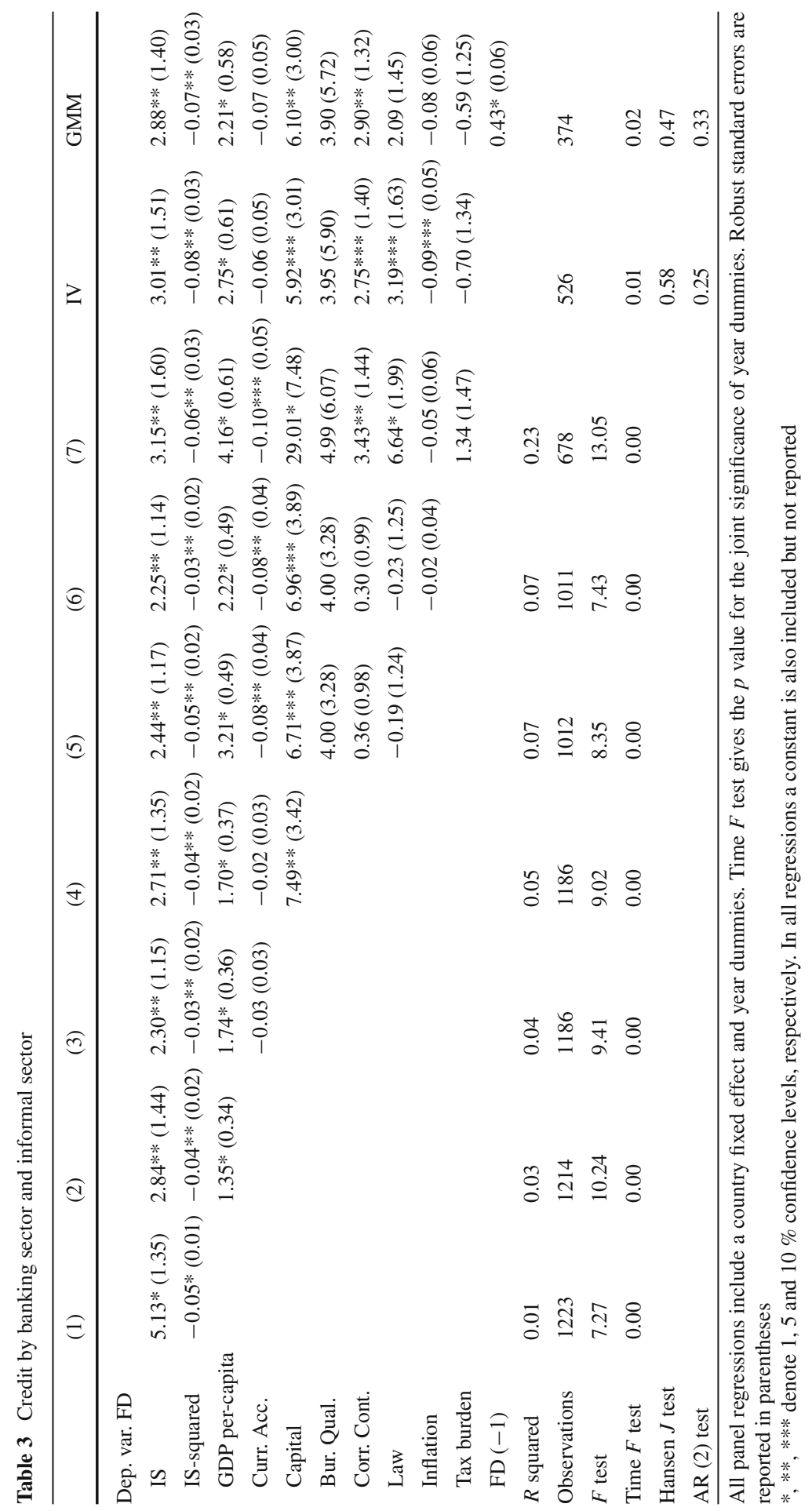




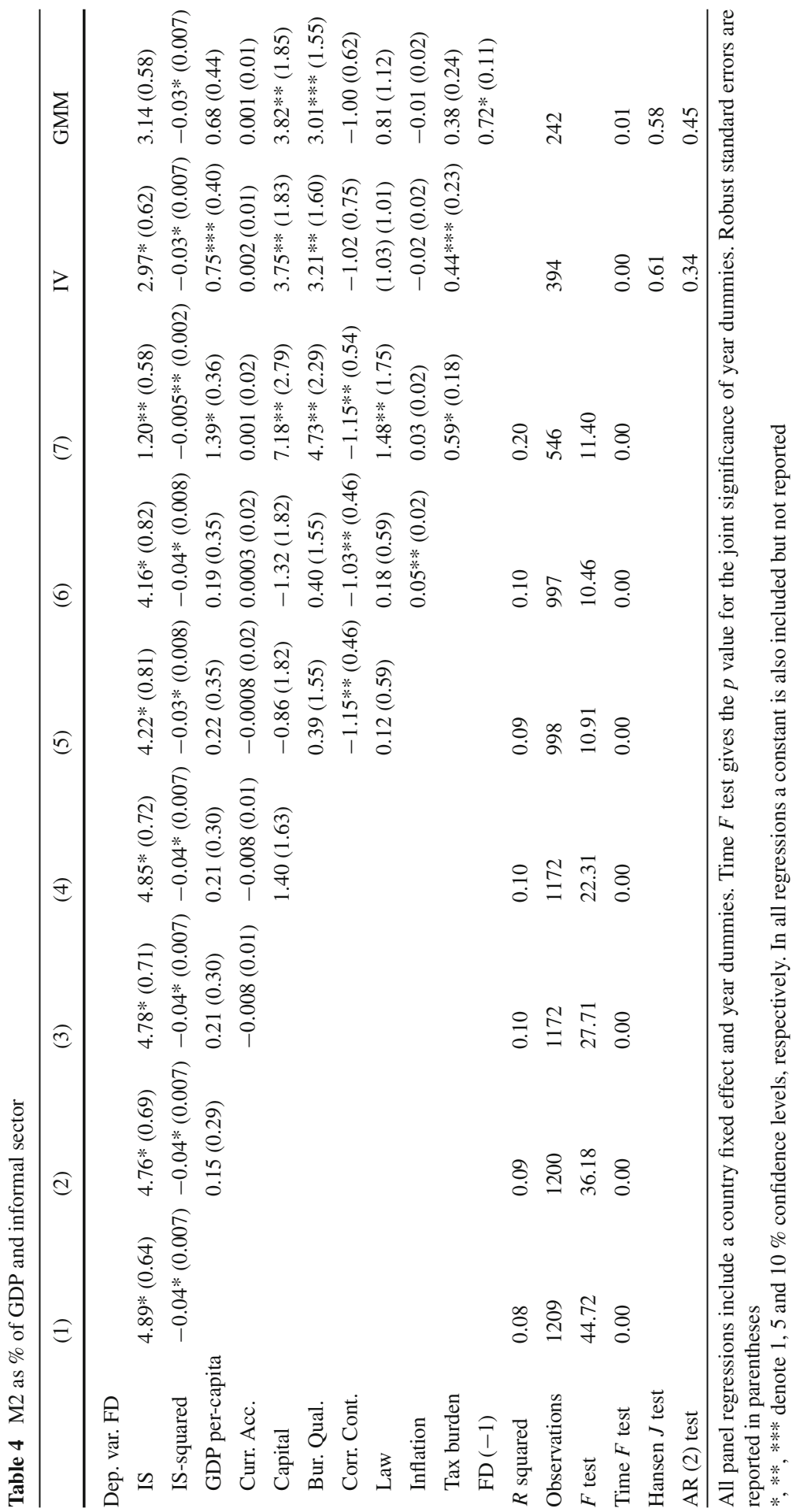


Table 5 presents results of the OLS regressions. In total we run 6 regressions, 2 for each measure of financial development. The results again given evidence in favor of the inverted-U relationship between financial development and the informal sector.

\subsection{Empirical results: mechanism behind the inverse-U relationship}

As presented in the previous section of the paper, our economic model identifies two channels through which informal sector size affects financial development. Specifically, on the one hand, informal sector harms financial development through increasing financial repression due to tax evasion. However, on the other hand, increasing informal sector size also facilitates financial development through easing the capacity constraint on the financial sector, thereby increasing the efficiency of the financial sector.

In order to provide empirically test this theory, we need measures for financial repression and financial efficiency. As a measure of financial repression due to tax evasion we use seignorage which we define as the ratio of the increase in the base money to total government revenue. For financial efficincy we have two candidate variables: (1) the value of banks net interest margin to total assets, shortly MARGIN and (2) banks overhead costs (COSTS) to total assets (both in \%) ${ }^{11}$ Notice that these financial sector indicators are used by Demirguc-Kunt and Maksimovic (1996), King and Levine (1993) and Levine and Zervos (1996) among many others. Obviously, when the MARGIN and COSTS get higher values, efficiency of the financial system decreases.

Table 6 reports panel system estimations ${ }^{12}$ using the ratio of value of banks net interest margin to total assets as the measure of financial efficiency whereas Table 7 does the same analysis using banks overhead costs to total assets. In this system we want to establish a positive correlation between informal sector size and both seigniorage and financial efficiency measures. Once these correlations are established, we expect that seignorage (financial efficiency) is negatively (positively) correlated with financial development.

Indeed, what we observe in both tables provides strong support for the presence of expected correlations and the mechanism of our theory. Larger (smaller) informal sector size is associated with higher (lower) levels of seigniorage and lower (higher) levels of MARGIN (or COSTS). Moreover, both higher (lower) levels of seigniorage and MARGIN (or COSTS) are associated with lower (higher) values of financial development measures.

In summary, these system estimations provide strong support for the mechanism through which informal sector size affects financial development in our model as well as for the nonlinear inverse- $U$ relationship between informal sector size and financial development.

\footnotetext{
11 We construct the seignorage data from World Development Indicators and the International Financial Statistics. The two measures for financial efficiency are taken from Beck et al. (2009).

12 In system estimations we only report results using fixed effects estimator; however we have also experimented various regressions using different estimators such as GMM with lagged independent variables as instruments and the maximum likelihood estimator obtained qualitatively similar results. These regression outputs are available upon request from the corresponding author.
} 


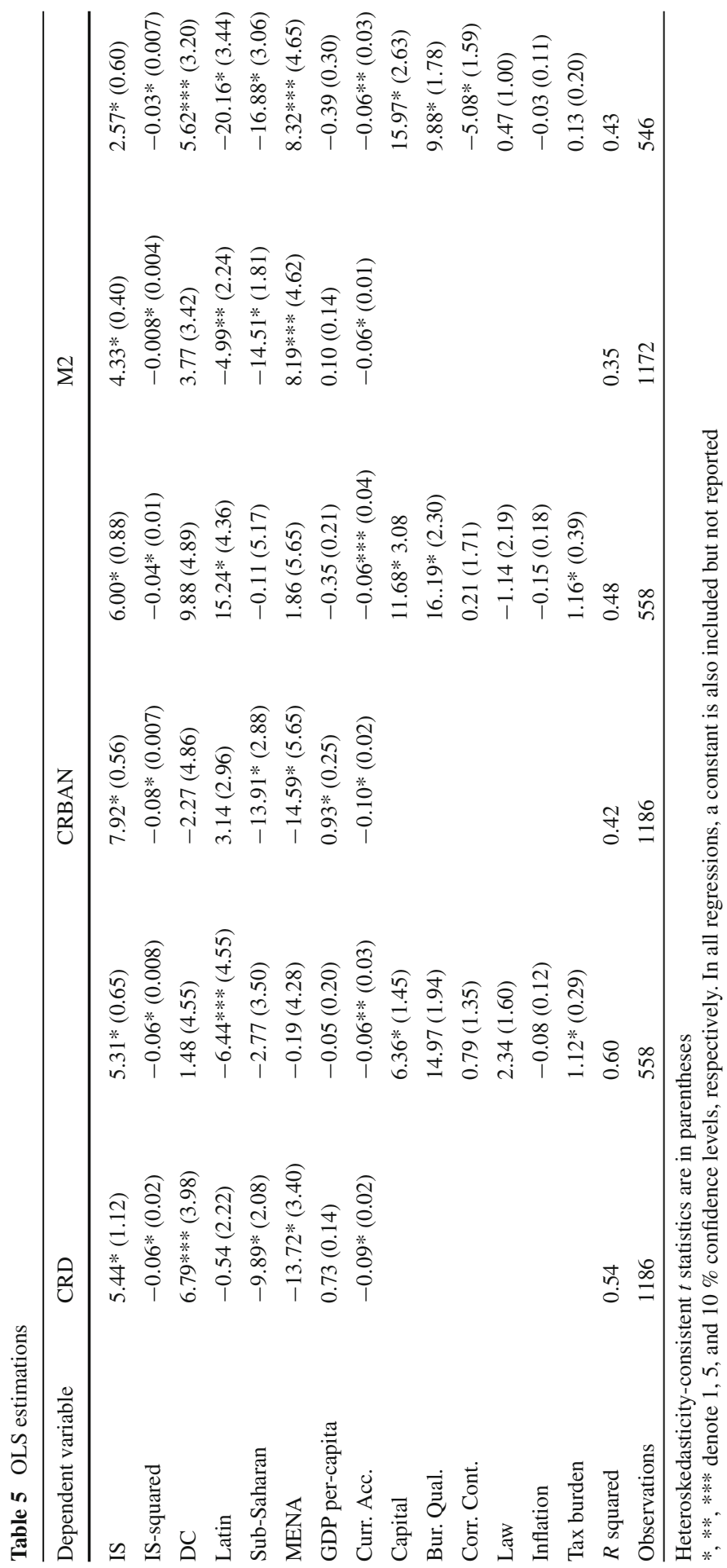




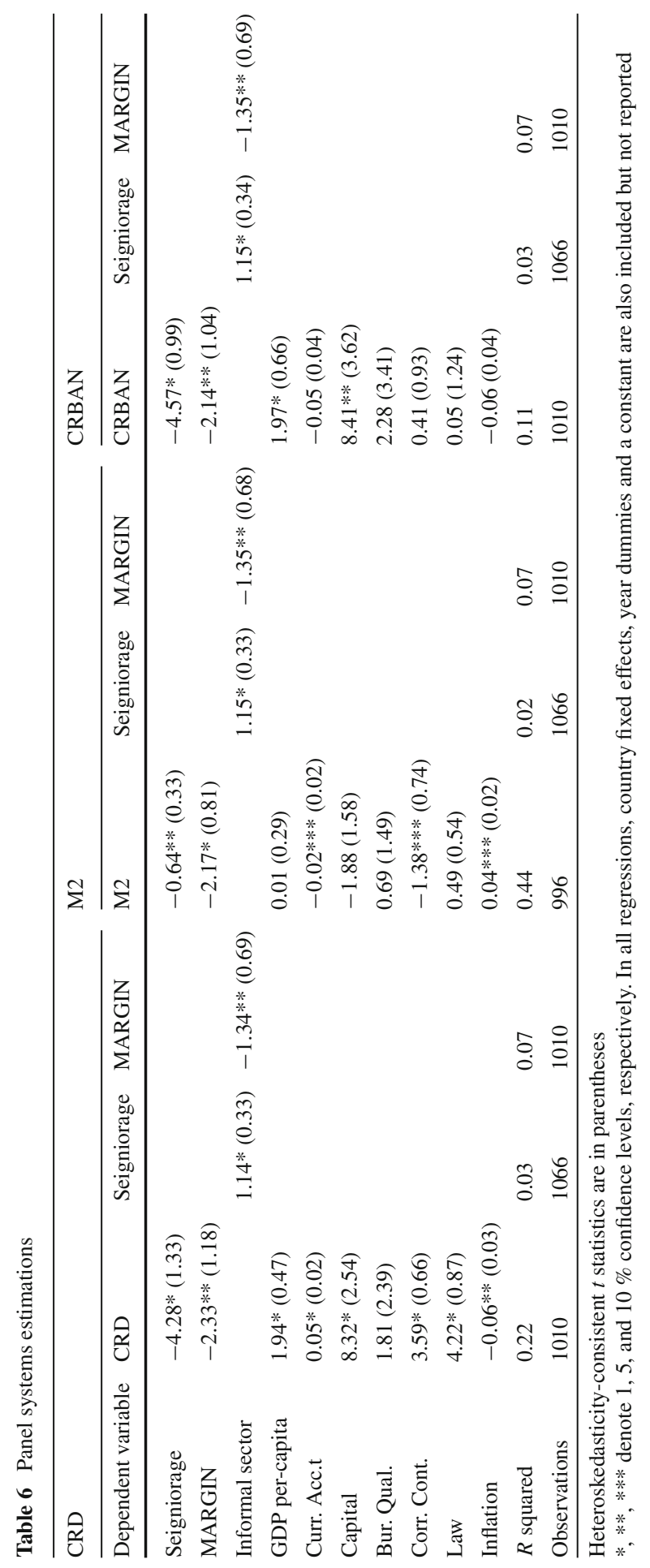




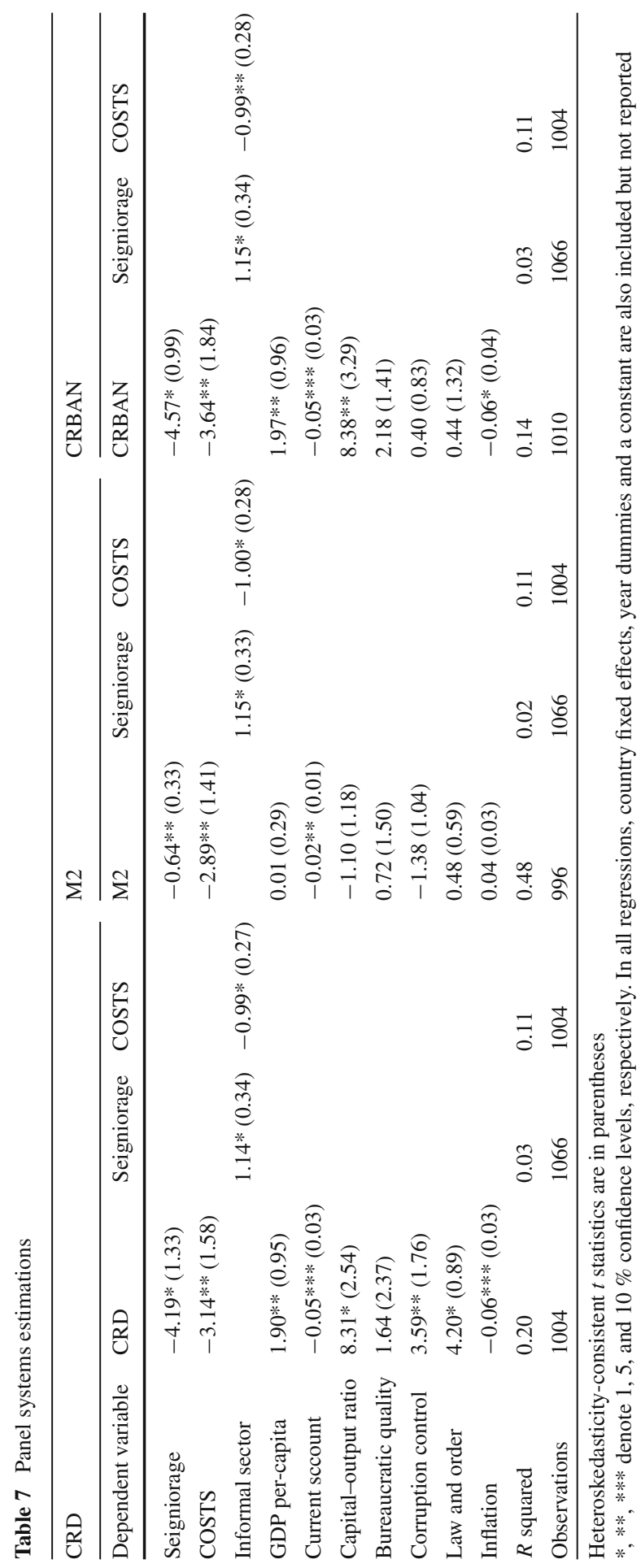




\section{Concluding remarks}

In this paper we studied the relationship between financial development and the size of the informal economy. We empirically document that there is an inverse-U relationship between financial development and informal sector size. The model we presented to account for this observation identified two channels through which the variation in the informal sector size affects the depth of the financial sector. The first channel is financial repression through which increasing informal sector size harms financial development. The second channel is financial efficiency through which informal sector size affects financial development in a beneficial way. Using a cross-country panel data set of 152 countries over the period 1999-2007 we also provided empirical support in favor of the presence of these channels our model identified.

Our study can be extended in a number ways to investigate various other macroeconomic issues linked to informal sector and financial development. One such issue is to investigate economic growth and how it is affected by the informal sector-financial sector linkage. Another such issue might be the determination of taxes by the government in a model of optimal taxation. These we leave to future work.

Acknowledgments For their helpful suggestions and comments we would like to thank to Thorsten Beck, Michael Binder, Chris Woodruff, Jenny Ligthart and Ping Wang.

Open Access This article is distributed under the terms of the Creative Commons Attribution License which permits any use, distribution, and reproduction in any medium, provided the original author(s) and the source are credited.

\section{References}

Acemoglu D, Zilibotti F (1997) Was Prometheus unbound by chance? Risk, diversification, and growth. J Pol Econ 105(4):709-751

Aghion P, Angeletos GM, Banerjee A, Manova K (2010) Volatility and growth: credit constraints and composition of investment. J M Econ 57(3):246-265

Aghion P, Bolton P (1997) A theory of trickle-down growth and development. Rev Econ Stud 64(2):151-172

Amaral PS, Quintin E (2006) A competitive model of the informal sector. J M Econ 53(7):1541-1553

Anderson TW, Hsiao C (1982) Formulation and estimation of dynamic models using panel data. J Econ 18:67-82

Antunes A, Cavalcanti T (2007) Start up costs, limited enforcement, and the hidden economy. Eur Econ Rev 51(1):203-224

Antunes A, Cavalcanti T, Villamil A (2008) The effect of financial repression and enforcement on entrepreneurship and economic development. J M Econ 55(2):278-297

Arellano M, Bond SR (1991) Some specification tests for panel data: Monte Carlo evidence and an application to employment equations. Rev Econ Stud 58:277-298

Arestis P, Demetriades P (1997) Financial development and economic growth: assessing the evidence. Econ J 107(442):783-799

Aruoba B (2010) Informal Sector. Government Policy and Institutions, Working Paper

Azariadis C (2007) Credit and growth under limited commitment. Macro Dyn 12(S1):20-30

Banerjee A, Newman A (1993) Occupational choice and process of development. J Pol Econ 101(2):274298

Boedo HM, D’Erasmo P (2009) Financial structure, informality and development. Virginia Economics Online Papers 374, University of Virginia.

Bose P (1998) Formal informal sector interaction in rural credit markets. J Dev Econ 56(2):265-280 
Boyd JH, Levine R, Smith BD (2001) The impact of inflation on financial sector performance. J M Econ 47(2):221-248

Beck T, Demirguc-Kunt A, Laeven L, Levine R (2008) Finance, firm size, and growth. JMCB 40(7):13791405

Beck T, Demirguc-Kunt A, Levine R (1999) A new database on financial development and structure, World Bank Policy Research Working Paper 2146

Beck T, Demirguc-Kunt A, Levine R (2000a) A new database on financial development and structure. WB Econ Rev 14:597-605

Beck T, Demirguc-Kunt A, Levine R (2000b) Law, politics and finance, World Bank Policy Research Working Paper 2585

Beck T, Demirguc-Kunt A, Levine R (2003) Law, endowments and finance. J Fin Econ 70(2):137-181

Beck T, Demirguc-Kunt A (2009) Financial institutions and markets across countries and over time: data and analysis World Bank Policy Research Working Paper No. 4943

Beck T, Levine R, Loayza N (2000) Financial intermediation and growth: causality and causes. J M Econ 46(1):31-77

Bencivenga V, Smith B (1991) Financial intermediation and endogenous growth. Rev Econ Stud 58(2):195209

Calderon C, Liu L (2003) The direction of causality between financial development and economic growth. J Dev Econ 72(1):321-334

Castro R, Clementi GL, MacDonald G (2004) Investor protection, optimal incentives and economic growth. Q J Econ 119(3):1131-1175

Cavalcanti T, Villamil A (2003) The optimal inflation tax and structural reform. Macroecon Dyn 7(3):333362

Chinn M, Ito H (2006) What matters for financial development? Capital controls, institutions, and interactions. J Dev Econ 81(1):163-192

Chinn M, Ito H (2007) Currentaccount balances, financialdevelopment and institutions: assaying the world saving glut. J Int M Fin 26(4):546-569

Christopoulos DK, Tsionas EG (2004) Financial development and economic growth: evidence from panel unit root and cointegration tests. J Dev Econ 73(1):55-74

Demirguc-Kunt A, Maksimovic V (1996) Stock market development and financing choices of firms. WB Econ Rev 10:341-369

Diamond D (1991) Monitoring and reputation: the choice between bank loans and directly placed debt. J Pol Econ 99(4):689-721

Dreher A, Schneider F (2010) Corruption and the shadow economy: an empirical analysis. Pub Ch 144:215238

Elgin C (2010) Political turnover, taxes and the shadow economy working papers 2010/08. Bogazici University, Department of Economics

Friedman E, Johnson S, Kaufman D, Zoldo-Lobaton P (2000) Dodging the grabbing hand: the determinants of unofficial activity in 69 countries. J Pub Econ 76(3):459-493

Greenwood J, Jovanovic B (1990) Financial development, growth, and the distribution of income. J Pol Econ 98(5):1076-1107

Hart K (2008) Informal economy, The New Palgrave Dictionary of economics, 2nd edn. In: Steven ND, Lawrence EB (eds) Palgrave Macmillan, Hampshire

Huang Y (2010) Determinants of financial development. Palgrave Macmillan, Hampshire

Ihrig J, Moe KS (2004) Lurking in the shadows: the informal sector and government policy. J Dev Econ 73(2):541-557

Johnson S, Kaufman D, Shleifer A (1997) The unofficial economy in transition. Br Pap Econ Act 28(2):159_ 140

Johnson S, Kaufman D, Zoido-Lobaton P (1998) Regulatory discretion and the unofficial economy. Am Econ Rev 88(2):387-392

Khan MS, Senhadji AS, Smith BD (2006) Inflation and financial depth. Macro Dyn 10(2):165-182

King R, Levine R (1993) Finance and growth: schumpeter might be right. Q J Econ 108:717-738

Levine R (1993) Finance and growth: schumpeter might be right. Q J Econ 108(3):717-737

Levine R (1997) Financial development and economic growth: views and agenda. J Econ Lit 35(2):688-726

Levine R, Zervos S (1998) Stock markets banks and economic growth. Am Econ Rev 26:1169-1183

Massenot B, Straub S (2011) Informal sector and economic growth: the supply of credit channel. IDEI Working Papers 685 
Marcet A, Marimon R (1992) Communication, commitment, and growth. J Econ Theory 58(2):219-249

Roubini N, Sala-i Martin X (1992) Financial repression and economic growth. J Dev Econ 39(1):5-30

Roubini N, Sala-i Martin X (1995) A growth model of inflation, tax evasion, and financial repression. J M Econ 35(2):275-301

Schich S, Pelgrin F (2001) Financial development and investment: panel data evidence for OECD countries from 1970 to 1997. Appl Econ Lett 9(1):1-7

Schneider F, Buehn A, Montenegro CE (2010) Shadow economies all over the world: new estimates for 162 countries from 1999 to 2007, World Bank Policy Research Working Paper 5356

Schneider F (2002) The size and development of the shadow economies of 22 transition and 21 OECD countries, IZA Discussion Papers, 514

Schneider F (2005) Shadow economies around the world: what do we really know? Eur J Pol Econ 21(3):598-642

Schneider F, Enste DH (2000) Shadow economies: size, causes, and consequences. J Econ Lit 38(1):77-114

Straub S (2005) Informal sector: the credit market channel. J Dev Econ 78(2):299-321

Torgler B, Schneider F (2007) Shadow economy. A panel analysis, IZA Discussion Papers, Tax Morale, Governance and Institutional Quality, p 2563

Townsend R (1979) Optimal contracts and competitive markets with costly state verification. J Econ Theory 21(2):265-293

Williamson SD (1987) Costly monitoring, loan contracts, and equilibrium credit rationing. Q J Econ 102(1):135-145 